\title{
SHORT-TERM EXPERIMENTS ON GRAFTING FRESH AND FROZEN CORNEAL TISSUE IN DOGS* ${ }^{\dagger}$
}

\author{
BY \\ F. O. MUELLER $\ddagger$ \\ From the Corneal Research Unit, Westminster-Moorfields Eye Bank at the \\ Royal Veterinary College, London
}

THE important factors in successful banking of corneal donor tissue at low temperature for full-thickness keratoplasty have been established. Dimethyl sulphoxide (DMSO) has been found to be superior to glycerol as a protective agent and the optimum rate of cooling appears to be one degree per minute down to $-15^{\circ} \mathrm{C}$. followed by a faster rate to $-197^{\circ} \mathrm{C}$. (Smith, 1962; Mueller and Smith, 1963; Kaufman, Escapini, Capella, Robbins, and Kaplan, 1966; Mueller, O'Neill, and Trevor-Roper, 1967).

In recent experiments five different techniques of thawing corneae have been investigated, and endothelial viability was assessed by the nitroblue-tetrazolium technique (Mueller, 1968). Results suggest that reduction of thawing time and dilution of DMSO concentration during thawing improve the appearance of endothelial cells judged by the number of stained cells and by the density of blue diformazan granules within dyed cells. It was decided to examine in grafting experiments the value and accuracy of the results of the nitroblue-tetrazolium technique, in particular when assessing the viability of donor material banked at $-197^{\circ} \mathrm{C}$. The results obtained with fresh unfrozen corneae were compared with the results of two techniques of corneal preservation which gave the highest and lowest numbers of stained endothelial cells.

\section{Material and Methods}

Mongrel dogs 20 to 30 pounds in weight were killed by intravenous phenobarbitone sodium and their eyes were enucleated and used as donor material. Several animals were anaesthetized and corneal graft operations were performed in one eye of each dog.

\section{Preparation of Donor Eyes; Cooling to, Banking at, and Thawing from $-197^{\circ} \mathrm{C}$.}

Stock-solution of tissue culture medium (Parker 199) 50 per cent. and calf serum 50 per cent. was stored at $+4^{\circ} \mathrm{C}$. Media containing dimethyl sulphoxide§ (DMSO) 8, 10, 12, or 14 per cent. (v/v) were made up immediately before cooling of corneae.

Pairs of donor eyes were stored at $18^{\circ} \mathrm{C}$. for 3 hours and fresh full-thickness grafts were cut from separated corneae and transplanted. The second cornea of each pair was immediately incubated with the medium containing nitroblue-tetrazolium for histochemical examination.

Other eyes were cooled to and banked at $-197^{\circ} \mathrm{C}$. The corneae with a rim of sclera were suspended at $+2^{\circ} \mathrm{C}$. in aluminium containers in $10 \mathrm{ml}$. medium containing DMSO for 6 minutes. In two series of experiments $3 \mathrm{ml}$. respectively of all suspending medium were aspirated and the containers were closed with plastic lids.

* Received for publication March 20, 1968.

+ Address for reprints: Eye Department, The Royal Free Hospital, London, W.C.1

¥ Present address: The Royal Free Hospital, London, W.C.1

$\S$ Sigma, London. 
All specimens were cooled with the endothelium facing downwards and with the scleral rim in contact with the bottom of the vessels. Cooling rate in the Matburn cooler was $1^{\circ} \mathrm{C}$. per minute to $-15^{\circ} \mathrm{C}$. and from then on $5^{\circ} \mathrm{C}$. per minute to $-60^{\circ} \mathrm{C}$. The containers were then transferred into the liquid nitrogen refrigerator and kept for several days at $-197^{\circ} \mathrm{C}$; ; at the time of operation containers were opened and thawed out at different rates. In the first series of experiments the containers holding corneae in $7 \mathrm{ml}$. frozen medium were put into a waterbath at $+50^{\circ} \mathrm{C}$. until almost all the ice had melted; thawing time was about 180 seconds and temperature of thawedout medium was approx. $+25^{\circ} \mathrm{C}$. In the second series the open containers which held the solid frozen corneae only were kept in the bare hand and $10 \mathrm{ml}$. stock solution at $+10^{\circ} \mathrm{C}$. were added; the final temperature of the thawed-out solution was approximately $+8^{\circ} \mathrm{C}$., and thawing took less than 60 seconds. All corneae were finally submerged in stock solution at either $+20^{\circ} \mathrm{C}$. or $+10^{\circ} \mathrm{C}$. for 6 minutes and full-thickness grafts were cut. One cornea of each pair of banked eyes was used as a control and was incubated after thawing.

\section{Surgical Method}

A posterior lamellar full-thickness corneal graft operation was the method used in all cases (Mueller and Formston, 1968). The superficial one-third of the corneal stroma was incised at the limbus and partially dissected (see Fig. 1A). After preparation of such an anterior flap the full-thickness donor disc was cut from the donor cornea without removing its epithelium. The cornea was placed into the hollow of a paraffin block and a $5.1 \mathrm{~mm}$. disc was cut from the endothelial side of the donor cornea. The disc was kept endothelium-upwards in a Petri dish and moistened by a drop of tissue culture medium. The centre of the deep lamellae of the host cornea was then cut with a $5.0 \mathrm{~mm}$. trephine and the host disc was dissected with scissors and discarded. The previously prepared donor disc was immediately placed into the recipient bed and the superficial corneal flap drawn across the graft and deep stroma. The flap was anchored in its original position by multiple direct virgin silk sutures on a $6 \mathrm{~mm}$. needle (see Fig. 1B).

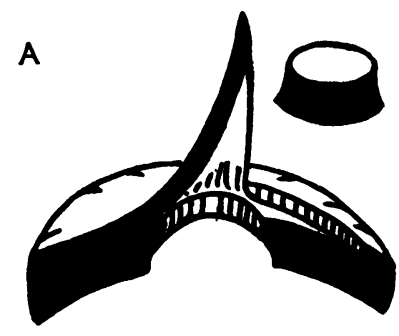

B

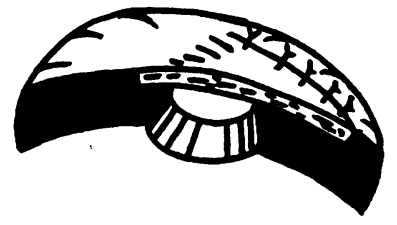

Fig. 1.-Technique of posterior lamellar full-thickness keratoplasty:

(A) Dissection of anterior corneal flap and preparation of posterior lamellar bed.

(B) Anterior lamellar flap sutured into place over the full-thickness donor disc.

Endothelium examined by the nitroblue-tetrazolium technique substrate sodium succinate unless otherwise stated.

\section{Post-operative Examination of Cornea and its Endothelium}

Eyes were examined on alternate days and oculentum atropine 1 per cent. was instilled into the fornices twice weekly; oculentum neomycin 0.5 per cent. was added whenever conjunctival discharge was noticed. Grafts were examined under 5 times magnification; detailed examination under neuroleptic analgesia (Hypnorm* $1 \mathrm{mg}$./kg. bodyweight) using the operating microscope took place at least once before the animals were killed.

\footnotetext{
* The Crookes Laboratories Ltd., Basingstoke, Hants.
} 
After operation the control corneae were thawed out and were incubated with the medium containing nitroblue-tetrazolium. Experimental animals were killed 1, 2, or 4 weeks after surgery and the grafted cornea was dissected and placed over a Latex rubber ring. The endothelial cavity of the cornea was filled with $0.8 \mathrm{ml}$. medium containing nitroblue-tetrazolium and was incubated at $+37^{\circ} \mathrm{C}$. for 90 minutes.

The incubation medium for all corneae was made up as follows and kept at $+37^{\circ} \mathrm{C}$. for repeated use:

$\begin{array}{llr}\text { Nitroblue-tetrazolium }^{* *} & & 10 \mathrm{mg} . \\ \text { Sodium succinate** } & (0.5 \text { molar }) & 2 \mathrm{ml} \\ \text { Trizma buffer** }^{* *} & \left(\mathrm{pH} 6.91 \text { at }+37^{\circ} \mathrm{C} \text { ) }\right. & 7 \mathrm{ml} .\end{array}$

After incubation the medium was drained off and the cornea was fixed in acetic alcohol (71 parts absolute ethanol, 25 parts glacial acetic acid, and 4 parts water) for at least 24 hours. After fixation the epithelium was removed and a full-thickness $9 \mathrm{~mm}$. central disc was cut. The disc was submerged in 30 per cent. ethanol for 30 minutes and afterwards in a glycerol solution (70 parts glycerol, 29 parts ethanol, and 1 part teepol) for 3 hours. The full-thickness corneal disc was mounted in absolute glycerol for microscopical examination of the endothelium. Dye was present between all the endothelial cells; cells which had suffered damage showed additional cytoplasmic diformazan deposits.

\section{Results}

\section{From Fresh Donor Material Kept at $+1^{\circ} \mathrm{C}$. for 3 Hours}

Eight full-thickness corneal discs were transplanted into the deep lamella of host corneae. The second cornea of each pair of donor eyes was examined and incubated with the medium containing nitroblue-tetrazolium.

The endothelium of stained control corneae appeared polyhedral; mainly regular hexagonal cells were observed and their size was uniform. Apart from a few deep blue stained cells, cytoplasmic stain was minimal in all cells; however, all intercellular tissue stained well (See Fig. 2A).

One week after operation the transplants were swollen. The oedema decreased, however, during the second week and after 4 weeks only a minimal stromal haze remained visible. The endothelial surfaces of grafts and host corneae were clear at all times after surgery (see Fig. 2B). Examination of mounted corneae revealed stained endothelial cells of host and graft of all eight corneae examined. The transplants showed polyhedral cells which were slightly irregular in outline and unequal in size when compared with the cells of the control corneae. In all specimens the cells at the edge of the graft were enlarged. The amount of cytoplasmic stain in the endothelial cells increased towards the second post-operative week, but was reduced 4 weeks after surgery. Intercellular dye was present between all transplanted cells; cytoplasmic diformazan deposits were clearly seen in 40 to 50 per cent. of cells. Cell nuclei could rarely be detected (see Fig. 2C).

The endothelial cells of the host were mostly hexagonal over the corneal periphery; towards the host-graft junction they became elongated whereas at the junction itself they were enlarged and irregular in shape. All cells showed intercellular dye and in addition, and particularly in cells close to the host-graft junction, cytoplasmic diformazan deposits were seen in over 50 per cent. of cells. The nuclei remained invisible in most endothelial cells of the host cornea (see Fig. 3A and 3B).

** Sigma, London. 
(A)

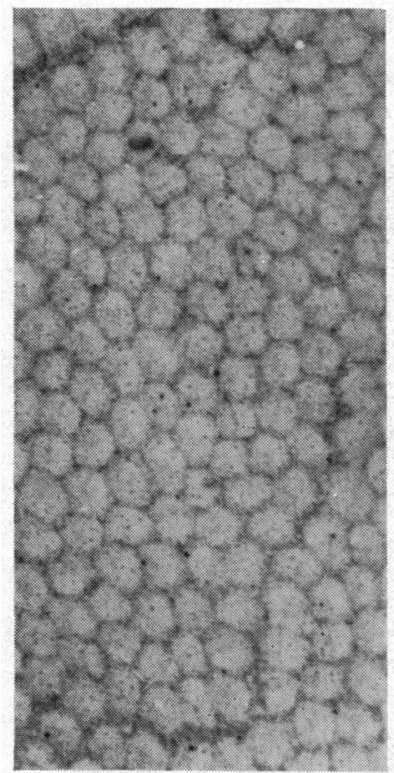

(в)

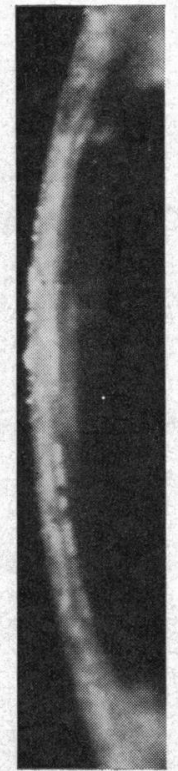

(c)

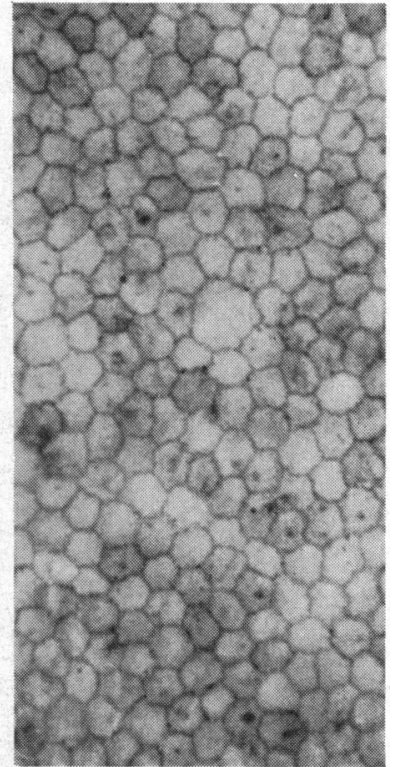

Fig. 2.-Fresh donor material kept at $+18^{\circ} \mathrm{C}$. for 3 hours:

(A) Stained endothelium of control cornea. $\times 240$.

(B) Slit-lamp appearance of graft 10 days after surgery. $\times 12$.

(C) Stained endothelium of graft 10 days after surgery. $\times 240$.

(A)

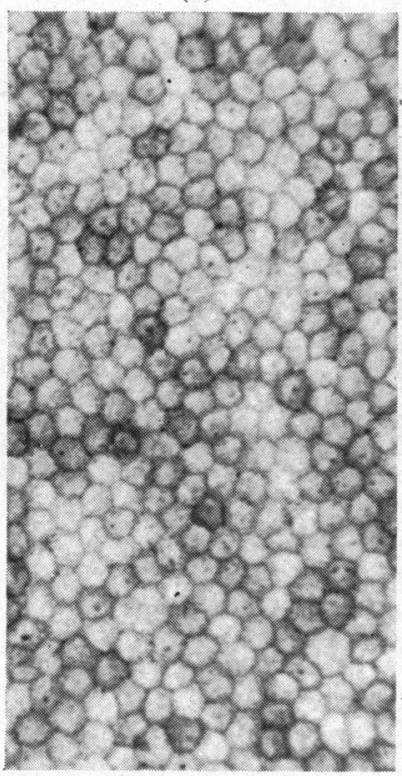

(B)

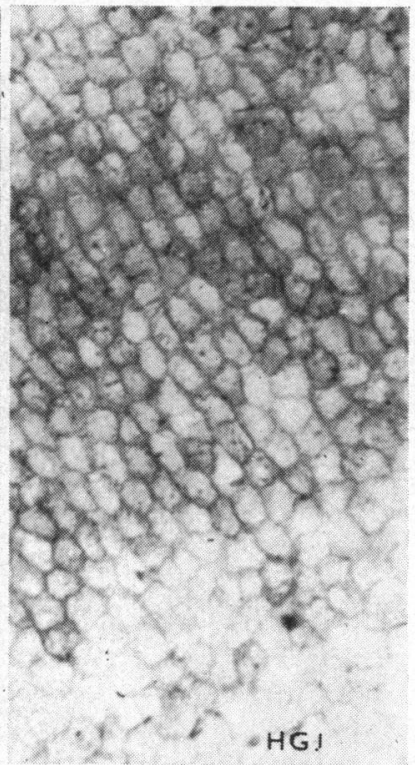

FIG. 3.-Endothelium of host cornea:

(A) Endothelium close to limbus. $\times 180$.

(B) Endothelium close to host-graft junction. $\times 180$ HGJ = Host-graft junction. 


\section{From Frozen Cornea Banked at $-197^{\circ} \mathrm{C}$.}

Cornea Banked in $7 \mathrm{ml}$. Medium.-36 corneae were suspended in $7 \mathrm{ml}$. medium containing 10,12 , or 14 per cent. DMSO. They were thawed out in a bath of $+50^{\circ} \mathrm{C}$. In eighteen experiments discs were cut and transplanted into the deep lamella of the host cornea. The grafts were swollen and slightly opaque at the end of the operation. The second cornea was thawed out and was immediately incubated using the same nitrobluetetrazolium method.

The endothelium of all control corneae kept in 10, 12, or 14 per cent. DMSO were deep blue stained and at least 80 per cent. of the endothelial cells showed maximal amounts of diformazan deposits (see Fig. 4A). In some areas endothelial cells could not be detected; here cells in the stroma of the cornea showed diformazan deposits.

The appearance of grafts during the first post-operative week was similar to that of fresh grafts examined at the same time after surgery. All transplants, however, examined during the second, third, and fourth weeks showed retrocorneal tissue attached to the grafts (see Fig. 4B and C).

(A)

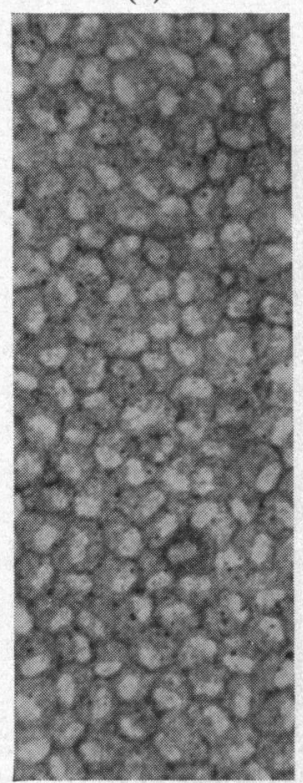

(в)

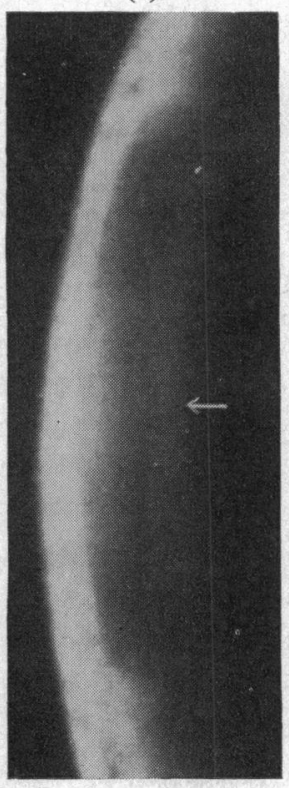

(c)

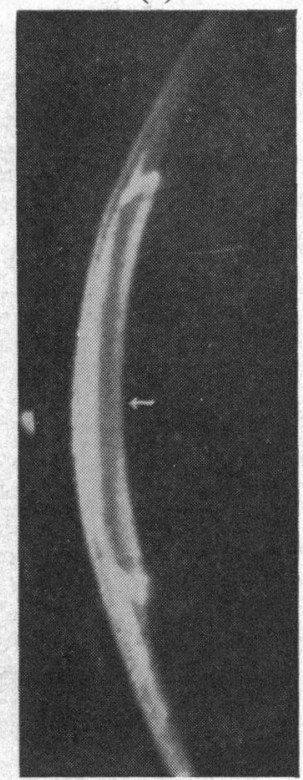

FIG. 4. - Canine donor material kept in $7 \mathrm{ml}$. medium (10 per cent. DMSO) at $-197^{\circ} \mathrm{C}$ :

(A) Endothelium of control cornea. $\times 240$.

(B) Slit-lamp appearance of failed graft 12 days after surgery. $\quad \times 12$.

(C) Slit-lamp appearance of failed graft 28 days after surgery. $\times 7 \cdot 5$. Arrow indicates site of post-graft membrane.

Examination of the stained and mounted corneae revealed total loss of endothelium of all grafts and red blood cells and white cells were found trapped into the retrocorneal tissue. Intercellular and cytoplasmic dye over the host cornea clearly showed the presence of all their endothelial cells. 
Corneae Banked in Vapour.-In 24 experiments corneae from pairs of donor eyes were suspended in a medium containing 8, 10, or 12 per cent. of DMSO. All fluid was aspirated or the corneae were transferred into dry pre-cooled aluminium containers and the vessels were cooled to and banked at $-197^{\circ} \mathrm{C}$. The corneae were thawed out by holding the container in the hand and by the addition of $10 \mathrm{ml}$. stock-solution at about $+10^{\circ} \mathrm{C}$. Fullthickness discs were cut and transplanted, and the grafts were found to be of normal thickness and clear at the end of the operation.

Control corneae were thawed out at the end of the surgical procedure and were immediately incubated with the staining medium. Examination of the mounted controls revealed a very small amount of diformazan deposits in 20 to 40 per cent. of cells; intercellular dye was barely visible. Equal density of stain was recorded in specimens kept in media containing 8, 10, or 12 per cent. DMSO (see Fig. 5A). The post-operative appearance of the grafts was similar to that of fresh transplants, slit-lamp examination showed normal posterior surfaces at all times, and the transplants were clear (see Fig. 5B and 5C; Fig. 6A).

(A)

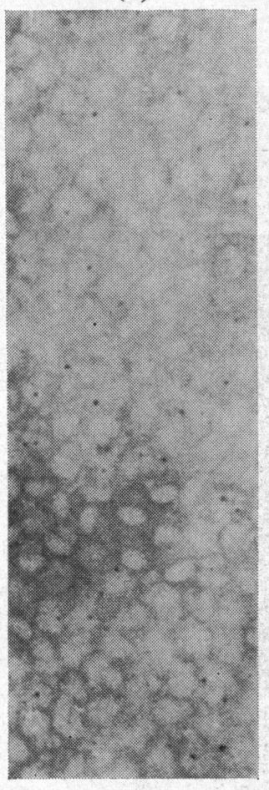

(в)

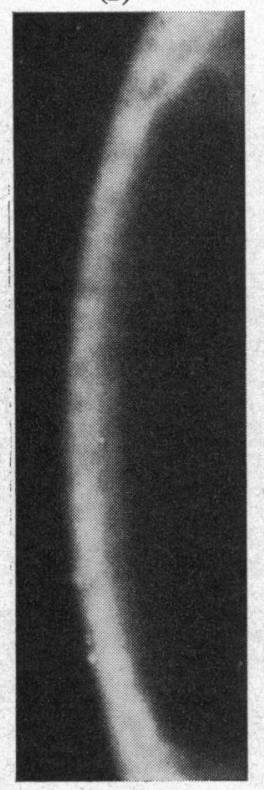

(c)

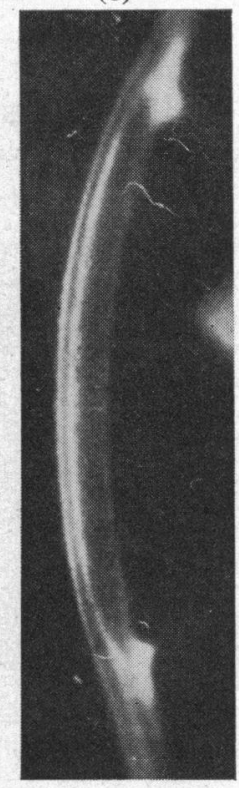

FIG. 5.-Donor material kept in vapour (10 per cent. DMSO) at $-197^{\circ} \mathrm{C}$.:

(A) Endothelium of control cornea. $\times 240$.

(B) Slit-lamp appearance of clear graft 14 days after surgery. Note that clear graft is not visible. $\times 12$.

(C) Slit-lamp appearance of clear graft 29 days after surgery. $\times 12$.

The endothelial cells were present over all the transplants, but two grafts only showed islands of enlarged cells when examined one week after the operation and were therefore failures. The size and shape of the cells over the remaining 22 grafts varied. Normal and medium-size cells were in the majority; cells at least ten times the size of normal cells were seen in seventeen out of 22 specimens (see Fig. 6B, Fig. 7A and B; and Fig. 8). Minimal amounts of cytoplasmic diformazan were observed in most of the normal and medium-size cells. Cell nuclei were seen only in the normal-sized endothelial cells of three grafts. Giant cells showed diformazan granules in the cytoplasm of three out of six grafts examined 2 weeks after surgery and in all eleven transplants examined 4 weeks after surgery. Several oval-shaped pale bodies were seen in giant cells in thirteen grafts. Intercellular dye was 
(A)

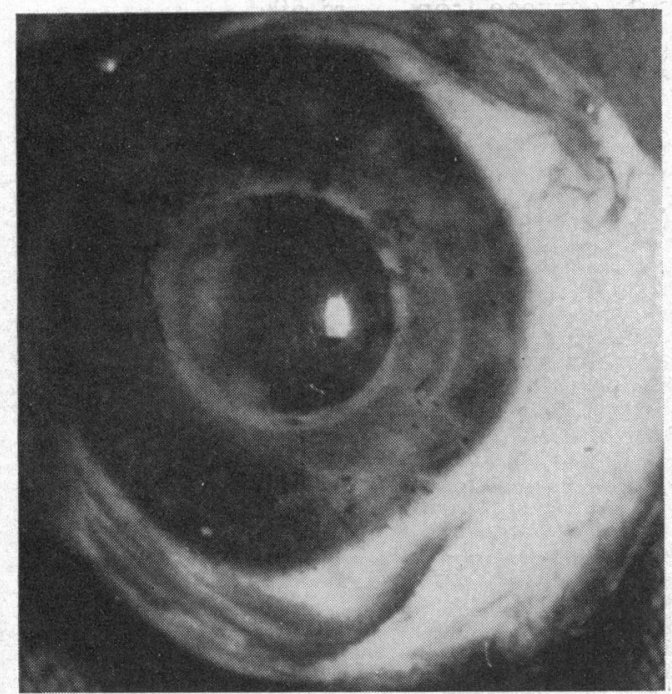

(B)

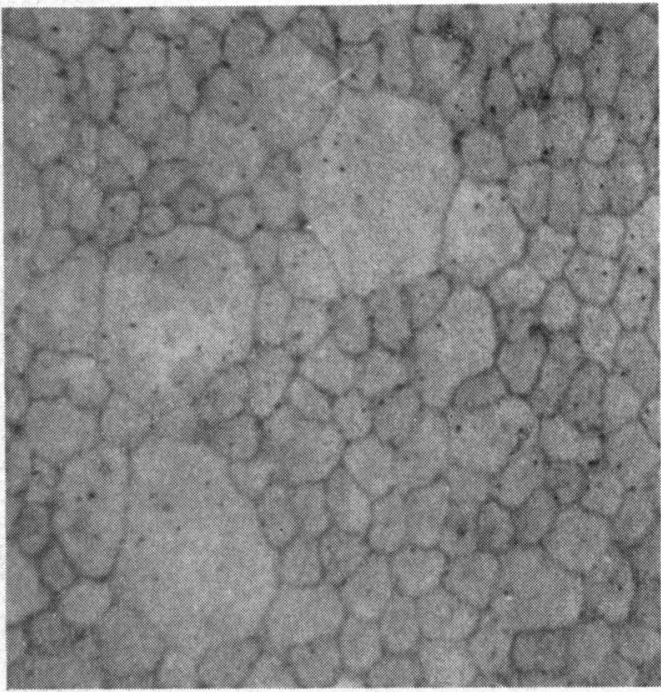

FIG. 6.-Posterior lamellar full-thickness graft 27 days after surgery:

(A) Donor kept in vapour (10 per cent. DMSO) at $-197^{\circ} \mathrm{C} . \times 4$.

Note opposite the light reflex the collection of graft epithelium deep to the corneal flap.

(B) Endothelium of graft in Fig. 6A. $\times 320$.

(A)

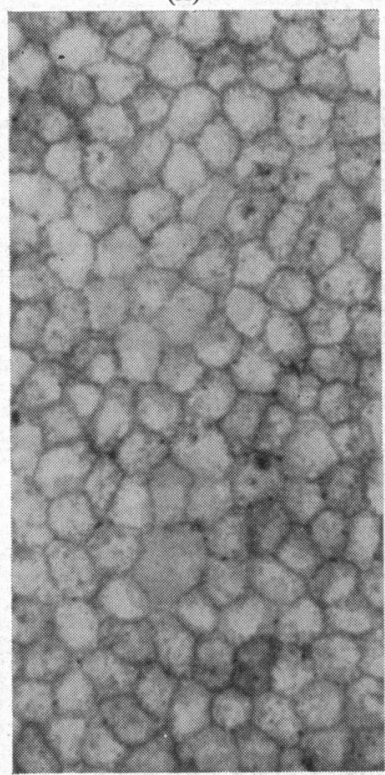

(в)

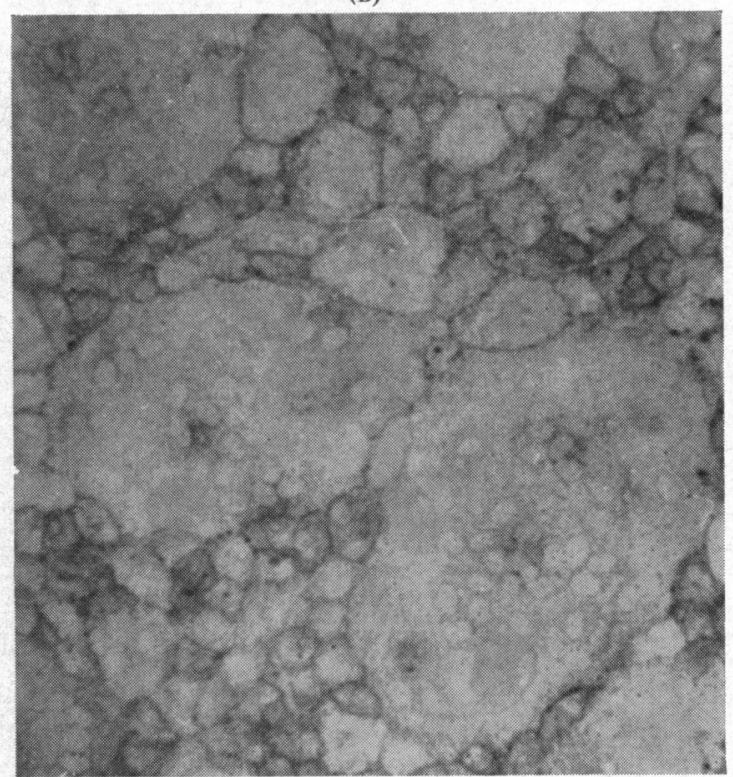

Fig. 7. Donor material kept in vapour (10 per cent. DMSO) at $-197^{\circ} \mathrm{C}$.

(A) Endothelial cells of graft 14 days after surgery. $\times 240$.

(B) Endothelial cells of graft 27 days after surgery. $\times 240$.

observed between all the cells of the grafts and host corneae, and the endothelium of the recipients showed features similar to those described in previous experiments. Corneae which had been suspended in 8,10 , or 12 per cent. DMSO gave similar results. 


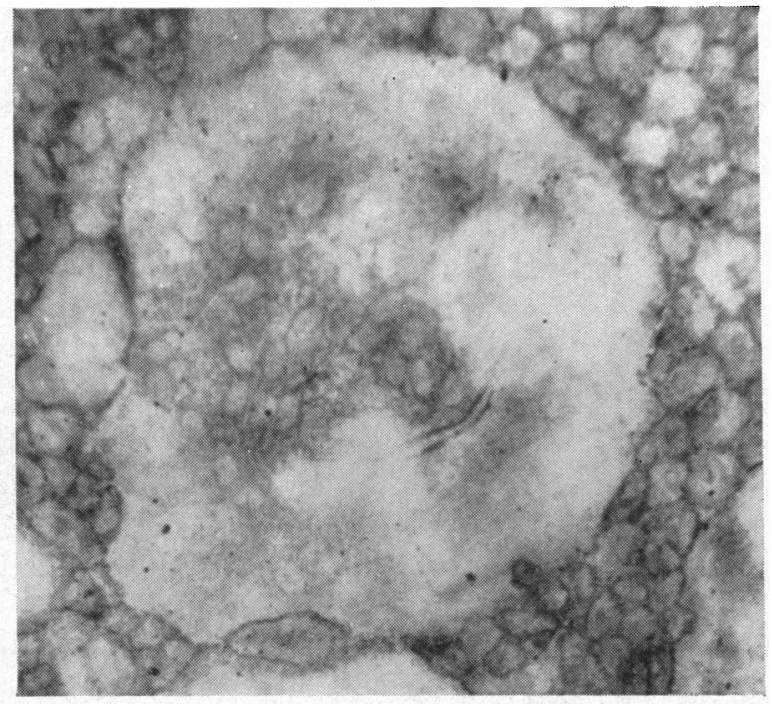

Fig. 8.-Giant cell of graft kept in vapour (10 per cent. DMSO) at $-197^{\circ} \mathrm{C} .14$ days after surgery.

\section{Discussion}

A posterior lamellar full-thickness graft technique using fresh donor material was developed and was consequently used in all experiments. The reasons for the disappointing results of partial full-thickness keratoplasties in the dog using fresh donor material have been given in another paper (Mueller and Formston, 1968).

With increasing surgical experience, operative complications could be eliminated and graft endothelium was preserved in all cases in which fresh corneal donor material was used. Similarly 22 out of 24 transplants of corneae cooled in vapour showed the presence of sufficient endothelium to give clear grafts. Long-term experiments with the above deep-freeze technique are indicated. By contrast the transplantation of corneae banked in $7 \mathrm{ml}$. medium failed to give clear transplants and endothelial loss continued to be observed. Inadequate storage of donor material appears the most likely reason for the poor results obtained with this technique and there is little justification for long-term experiments. The purpose of the short-term grafting experiments was to eliminate the inferior method.

No attempt was made to remove the epithelium from donor corneae before cooling or after thawing as this might possibly have damaged the endothelium while the risk of hostresponse was small in short-term experiments.

The nitroblue-tetrazolium technique (substrate sodium succinate) described in this paper differs from the technique used in the study on corneal preservation (substrate b-OH butyrate) which has been described in a previous paper (Mueller, 1968). Endothelium examined by either technique showed cytoplasmic diformazan deposits in a number of cells. Corneae treated by the method given in the present paper showed in addition intercellular dye between all graft and host endothelial cells irrespective of the presence or absence of cytoplasmic diformazan. Fig. $2 \mathrm{C}$ is to be compared in this respect with Fig. 9A. An advantage of the succinic dehydrogenase technique used in these investigations is that outlines of all cells are visible, and their size and shape as well as cell loss are always recognized with ease. Incubation techniques using sodium lactate or b-OH butyrate are to be preferred when assessing pathological changes in endothelial cells of corneal donor 
material; differentiation between cells containing dye and unstained cells is accurate (PeñaCarrillo and Polack, 1964; O'Neill, Mueller, and Trevor-Roper, 1967; Polack, 1968). The loss of endothelial cells, however, is difficult to recognize. The corneal endothelium which was partly destroyed became detached from Descemet's membrane during incubation. The denuded area could be recognized in between unstained endothelial cells only by the small amount of diformazan deposits in the stromal cells; the stromal cells covered by endothelium lacked all dye.

(A)

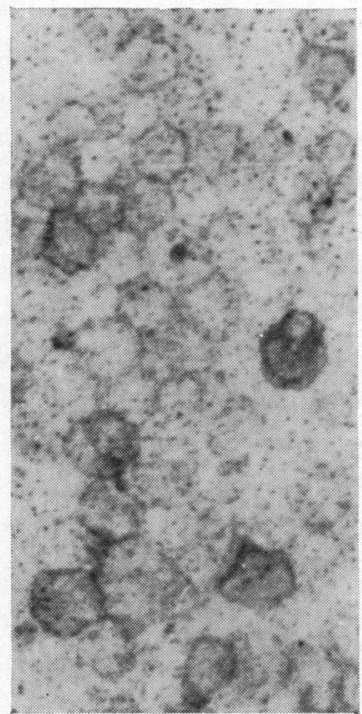

(B)

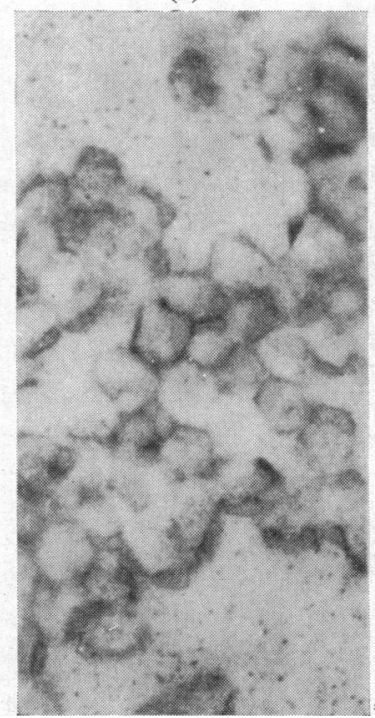

(c)

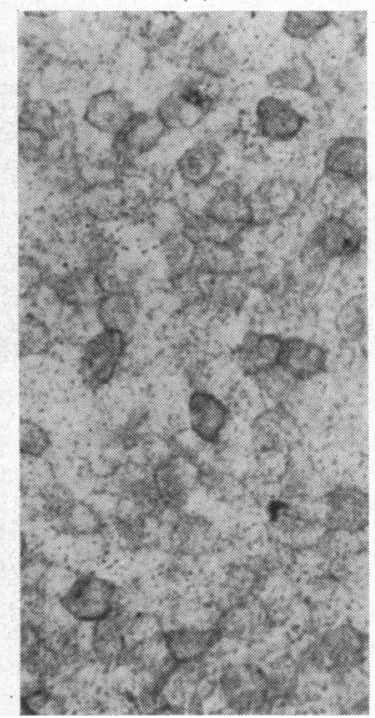

(D)

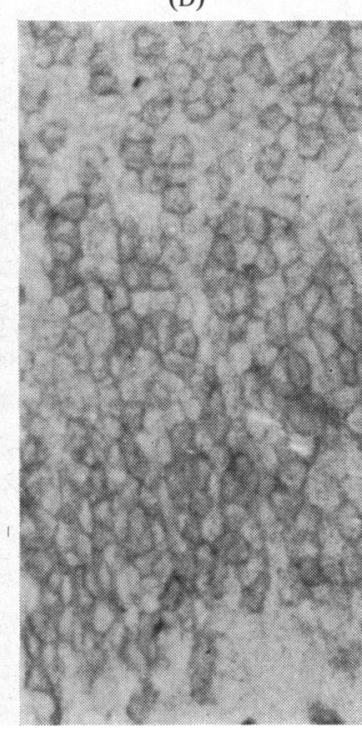

FIG. 9.-Nitroblue-tetrazolium technique substrate b-OH butyrate:

(A) Stained endothelium of fresh graft 14 days after surgery. $\times 240$.

(B) Stained endothelium of host cornea 5 days after anterior lamellar graft surgery. $\times 240$.

(C) Endothelial cells of host cornea after perforating keratoplasty. Limbal cells. $\times 180$.

(D) Endothelial cells of host cornea after perforating keratoplasty. Cells at host-graft junction. $\times 100$.

It is of interest to note that diformazan deposits were seen in endothelial cells of host corneae after perforating corneal graft operations and also after anterior lamellar transplantations incubated with either staining media (Fig. 3A and B; Fig. 9B, C, D). There is little doubt that these stained host cells are viable. The presence of diformazan in endothelial cells seems to indicate pathological changes but not necessarily irreversible damage leading to cell death. Furthermore it appears extremely difficult to judge the severity of cell damage by the density of diformazan granules in the cells unless cell destruction as such is visible. Cell damage is estimated by comparing corneal specimens treated by the same nitroblue-tetrazolium technique. The results obtained require confirmation by tissue transplantation because a clear corneal transplant is as yet the only proof of the existence of a functioning graft endothelium.

A high proportion of surviving cells was seen in frozen transplants whose controls showed faint staining of cytoplasm, nevertheless, cell survival was lower than in fresh transplants in spite of the low number of stained endothelial cells in either of the controls. The results support the view that the amount of diformazan in cells and the number of stained cells serve only as a guide in assessing overall cell viability. 
A nuclear stain was not used to clarify the signification of the many oval-shaped bodies observed in enlarged cells of several frozen grafts. The possibility that these bodies are artefacts cannot be excluded, but experience with the nitroblue-tetrazolium stain suggests that they represent nuclei of giant endothelial cells. Other workers have described giant cells in the endothelium of arteries, veins, and lymphatic vessels (Kaufmann, 1929; Poole, Sanders, and Florey, 1958; Sinapius, 1958; Florey, Poole, and Meek, 1959). Enlarged corneal endothelial cells were seen close to the host-graft junction and have been observed by Binder and Binder (1957) and by Salceda (1967) in the rabbit cornea. These multinucleated giant cells of vessels and of the cornea resemble a syncytium, the nuclei failing to become separated into individual cells.

Enlarged endothelial cells were observed after grafting corneal discs cut from fresh donor material which had been stored as long as 3 days at $+4^{\circ} \mathrm{C}$. In further experiments the tip of a hypodermic needle was drawn three times across the endothelium of fresh discs before transplantation. In all these grafts enlarged and irregular-shaped cells were seen in areas in which endothelium had possibly been damaged before transplantation but giant multinucleated cells were not observed. Part of a damaged control disc as well as a damaged graft 8 days after surgery are shown in Fig. 10A and B.
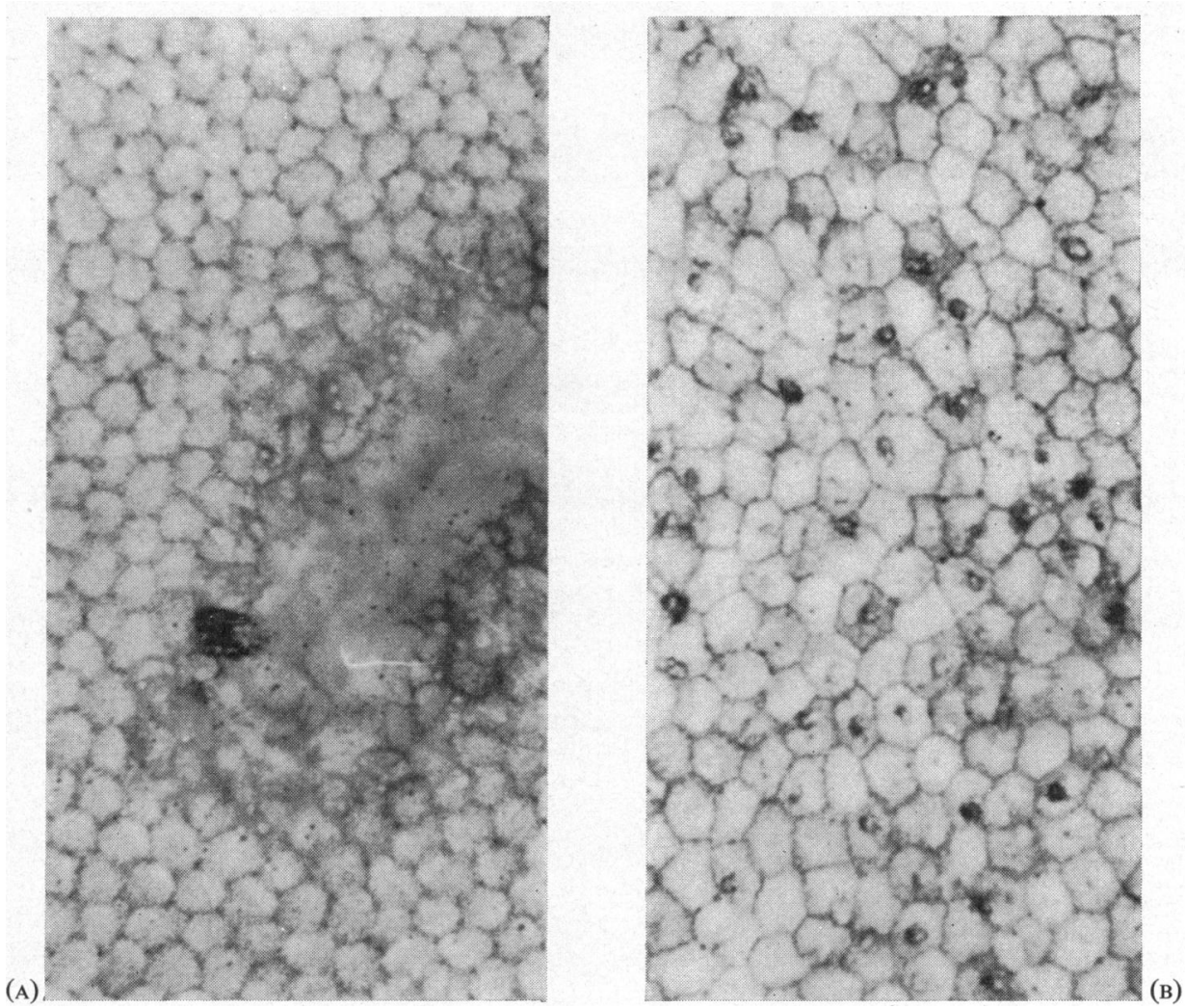

Fig. 10.-Endothelium of fresh cornea damaged by hypodermic needle:

(A) Stained endothelium of control cornea. $\times 320$.

(B) Stained endothelium of graft 8 days after surgery. $\times 320$.

Several of the clear frozen grafts showed a cell reduction to about 60 per cent. yet they gave clear transplants. The results are in agreement with the findings of Salceda (1967), who reported clear corneal transplants in rabbits which showed a reduction in cell popula- 
tion by 50 per cent. Further investigations into the relationship between clear corneal transplants and the percentage of endothelial cells might be of the greatest interest.

The technique of banking the human cornea suspended in medium at $-197^{\circ} \mathrm{C}$. gave a high success rate of corneal transplants, but canine donor material banked by the same technique failed to give clear grafts. It appears that the endothelium of the human cornea survives freezing better than canine endothelium. The improved technique of deep-freeze preservation here tested with success in the dog may prove to be far superior to the presently used technique of low-temperature storage of human corneal donor material.

\section{Summary}

A posterior lamellar full-thickness technique of homografting fresh and frozen canine corneae was used in all experiments. Two techniques of deep-freeze preservation were selected from a group of experiments previously reported.

Separated corneae were suspended in a solution containing $8,10,12$, or 14 per cent. dimethyl-sulphoxide for 6 minutes and cooled thereafter in $7 \mathrm{ml}$. medium or in vapour to $-197^{\circ} \mathrm{C}$. Corneae suspended in $7 \mathrm{ml}$. medium were thawed out in 180 seconds and those in vapour in less than 60 seconds.

The dogs on which a posterior lamellar graft was performed were killed within 30 days of surgery. Eight of eight grafts cut from fresh material were clear and endothelium of all grafts was present at all times when examined histochemically. Eighteen deep-frozen corneae which had been suspended in $7 \mathrm{ml}$. medium during cooling and banking showed post-graft membranes and graft-endothelium was absent. 22 of 24 grafts which had been cooled in vapour were clear and graft-endothelium was present whenever examined after surgery, but many endothelial cells were enlarged and "multinuclear" giant cells were also observed. All grafted corneae were examined by the nitroblue-tetrazolium technique, and the cytoplasm of damaged cells stained blue.

I am indebted to Dr. A. U. Smith and to her colleagues of the Clinical Research Centre at the National Institute for Medical Research, Mill Hill, for unceasing encouragement and advice throughout the years of my research. I also wish to record my thanks to members of the staff of the Royal Veterinary College, Camden Town, in particular to Prof. C. Formston, F.R.C.V.S., for invaluable help. My thanks to Mr. R. A. Morton, Westminster Medical School, who helped in preparing the illustrations.

\section{REFERENCES}

BINDER, R. F., and Binder, H. F. (1957). A.M.A. Arch. Ophthal., 57, 11.

Florey, H. W., Poole, J. C. F., and Meek, G. A. (1959). J. Path. Bact., 77, 625.

Kaufman, H. E., Escapini, H., Capella, J. A., Robbins, J. E., and Kaplan, M. (1966). Arch. Ophthal. (Chicago), 76, 471.

Kaufmann, E. (1929). "Pathology for Students and Practitioners", trans. S. P. Reimann, vol. 1, p. 80. Lewis, London.

Mueller, F. O. (1968). Brit. J. Ophthal., 52, 649. and FoRMSTON, C. (1968). In preparation. , O'NeILl, P., and Trevor-Roper, P. D. (1967). Brit. J. Ophthal., 51, 227.

and SMrth, A. U. (1963). Exp. Eye Res., 2, 237.

O'Neill, P., Mueller, F. O., and Trevor-Roper, P. D. (1967). Brit. J. Ophthal., 51, 13.

Pearse, A. G. E. (1960). " "Histochemistry, Theoretical and Applied", 2nd ed. Churchill, London.

Peña-Carillo, J., and Polack, F. M. (1964). Arch. Ophthal. (Chicago), 72, 811.

Polack, F. M., Kudo, T., and TaKahashi, G. H. (1968). I Ibid., 79, 205.

Poole, J. C. F., SANDers, A. G., and Florey, H. W. (1958). J. Path. Bact., 75, 133.

(1959). Ibid., 77, 637.

SALCEDA, S. R. (1967). Arch. Ophthal. (Chicago), 78, 745.

SinAPIUS, D. (1958). Z. Zellforsch., 47, 560.

SMITH, A. U. (1962). Int. ophthal. Clin., 2, 731. 